Zeszyty Naukowe Szkoły Głównej Gospodarstwa Wiejskiego w Warszawie

Problemy Rolnictwa Światowego tom 18 (XXXIII), zeszyt 4, 2018: 152-161

DOI: 10.22630/PRS.2018.18.4.106

Agata Grużewska $^{1}$, Krystyna Zarzecka ${ }^{2}$, Marek Gugala ${ }^{3}$

${ }^{1-3}$ Uniwersytet Przyrodniczo-Humanistyczny w Siedlcach

\title{
Analiza rynku owoców jagodowych - wybrane elementy
}

\section{Analysis of the Berry Market - Selected Elements}

\begin{abstract}
Synopsis. Celem pracy była identyfikacja zmian zachodzących na rynku owoców jagodowych w Polsce oraz w wybranych krajach Unii Europejskiej, w latach 2006-2017. W opracowaniu dostępnych danych i prezentacji wyników badań wykorzystano metody opisowe i porównawcze. W publikacji wykorzystano dane GUS oraz FAO, dotyczące powierzchni upraw, wielkości produkcji i spożycia owoców, ze szczególnym uwzględnieniem owoców jagodowych, na świecie i wybranych krajach Unii Europejskiej oraz w Polsce. Analizą objęto lata 2006-2017 dla Polski w odniesieniu do powierzchni upraw i wielkości produkcji, lata 2006-2017 w odniesieniu do wielkości spożycia, a w badaniach Polski na tle świata i wybranych krajów UE, ze względu na wielkość produkcji i powierzchnię upraw owoców jagodowych, uwzględniono rok 2016.
\end{abstract}

Slowa kluczowe: owoce jagodowe, produkcja, konsumpcja

\begin{abstract}
The aim of the work was to identify changes taking place in the market of berries in Poland and selected European Union countries from 2006 to 2017. Descriptive methods were used to analyse the available data and present the study results. The work is based on GUS (the Main Statistical Office in Poland) and FAO data pertaining to cropped area, production volume and fruit consumption level, paying special attention to berries, in Poland, selected European Union countries and worldwide. Data for the period 2013-2017 was considered for cropped area and production volume in Poland, 20062017 for consumption level, and the year 2016 for production volume and area under berry plants in Poland against the background of the world and selected EU countries.
\end{abstract}

Key words: berry fruit, production, consumption

JEL Classification: O13, Q17

\section{Wprowadzenie}

Owoce stanowią ważny element zdrowej diety. Polacy chętnie spożywają rodzime gatunki, a szczególnie jabłka, gruszki, śliwki, maliny oraz truskawki (Tomek i Robinson 2001). Od wielu lat wzrasta udział organizacji producenckich w sprzedaży owoców i warzyw (Sobczak i in., 2013). Już w 1972 roku wprowadzone zostało rozporządzenie Unii Europejskiej „O wspólnej organizacji rynku owoców i warzyw”. Aktualnie również polscy producenci korzystają ze wsparcia finansowego z funduszy UE, wykorzystując środki na

\footnotetext{
${ }^{1}$ dr hab., UPH w Siedlcach, Zakład Ekonomiki Rolnictwa i Agrobiznesu, ul. B. Prusa 14, 08-110 Siedlce, e-mail: agata.gruzewska@uph.edu.pl; https://orcid.org/0000-0003-3786-4016

2 prof. dr hab., UPH w Siedlcach, Katedra Agrotechnologii, ul. B. Prusa 14, 08-110 Siedlce,

e-mail:krystyna.zarzecka@uph.edu.pl; https://orcid.org/0000-0002-7792-6448

${ }^{3}$ dr hab., UPH w Siedlcach, Katedra Agrotechnologii, ul. B. Prusa 14, 08-110 Siedlce,

e-mail: marek.gugala@uph.edu.pl; https://orcid.org/0000-0001-5048-3432
} 
rozwój produkcji i poprawę konkurencyjności na rynku wspólnotowym, a nawet globalnym (Jabłońska, 2006). Produkcja owoców jagodowych stanowi bardzo ważny segment krajowej produkcji sadowniczej (Paszko i in., 2016). Badania Szuka i in. (2016) wykazały, że w latach 2008-2013 produkcja owoców w Polsce była blisko dwukrotnie większa od krajowego spożycia. Badania Gheribi (2012) potwierdziły malejące miesięczne spożycie owoców (o 8\%) i warzyw (o 15\%) w latach 2004-2008. Wyniki badań dotyczące częstotliwości spożycia owoców wykazały, że najczęściej spożywali je konsumenci w wieku 31-45 lat oraz powyżej 60 lat (Jąder, 2017). Natomiast $\mathrm{z}$ danych GUS (www.stat.gov.pl) wynika, że przeciętne miesięczne spożycie owoców w ostatnich latach (2010-2016) zwiększyło się o blisko 6\%, przy czym zaobserwowano malejąca wartość omawianego wskaźnika w połączeniu ze zwiększeniem liczby osób w rodzinie. W rodzinach powyżej pięciu osób wskaźnik ten, w 2016 roku, był o blisko $40 \%$ mniejszy niż średnia ogółem.

Do owoców jagodowych zalicza się m.in: borówkę wysoką, malinę, truskawkę i czarną porzeczkę. Właściwości lecznicze borówki wysokiej znane są od lat. Owoce stosowane są w profilaktyce m.in. chorób cywilizacyjnych i układu krążenia (Pliszka, 2002). Owoce maliny były przez tysiąclecia wykorzystywane w celach odżywczych i leczniczych (Krauze-Baranowska, 2007). Pod względem zawartości żelaza i fosforu truskawki znajdują się na pierwszym miejscu wśród produkowanych w Polsce owoców (Karabela, 2006). Czarna porzeczka ma właściwości przeciwgnilne i przeciwszkorbutowe. Wywar z owoców hamuje procesy zapalne w nerkach i kanalikach żółciowych, obniża ciśnienie krwi i łagodzi bóle reumatyczne (Karabela, 2008).

Ze względu na te cenne właściwości owoców jagodowych Związek Sadowników RP zainicjował w 2015 r. trzyletni Program Informacyjny „Niezwykłe właściwości zwykłych owoców". W jego ramach prowadzona jest edukacja konsumentów w zakresie korzyści płynących ze spożywania europejskich owoców jagodowych. Program skoncentrowany jest na promocji truskawek, borówek, malin i czarnych porzeczek i jest kampanią promocyjnoinformacyjna, realizowaną na rynkach pięciu krajów: Polski, Austrii, Szwecji, Finlandii i Czech (Portal promocji eksportu).

\section{Materiał i metody badań}

Celem pracy była identyfikacja zmian zachodzących na rynku owoców jagodowych w Polsce oraz w wybranych krajach Unii Europejskiej, w latach 2006-2017. W opracowaniu dostępnych danych statystycznych i prezentacji wyników badań wykorzystano metody opisowe i analizę porównawczą. Część wyników przedstawiono graficznie.

W publikacji wykorzystano dane GUS oraz FAO, dotyczące powierzchni upraw, wielkości produkcji i spożycia owoców, ze szczególnym uwzględnieniem owoców jagodowych, na świecie i wybranych krajach Unii Europejskiej oraz w Polsce. Analiza objęto lata 2006-2017 dla Polski w odniesieniu do powierzchni upraw, wielkości produkcji i w odniesieniu do wielkości spożycia, a w badaniach Polski na tle świata i wybranych krajów UE uwzględniono rok 2016. Wybór lat do badań podyktowany był dostępnością danych statystycznych GUS, w odniesieniu do spożycia oraz danych FAO.

$\mathrm{W}$ analizie danych dla Polski zastosowano jednopodstawowe (o podstawie stałej) indywidualne indeksy dynamiki, w odniesieniu do roku 2006. Obliczenia wykonano zgodnie z wzorem (Ostasiewicz i in., 1999): 


$$
i_{n / 1}=\frac{y_{n}}{y_{1}}
$$

zakładając, że:

$y_{n}$ - wartość cechy w roku badanym $(2007, \ldots, 2017)$,

$y_{1}$ - wartość cechy w roku bazowym 2006.

Analizując wielkość spożycia owoców ogółem, jagodowych, południowych oraz jabłek zastosowano współczynnik korelacji Pearsona.

\section{Wyniki badań i omówienie}

Powierzchnia uprawy truskawek w Polsce, w latach 2006-2017 (rys. 1), podlegała niewielkim wahaniom, wynosząc średnio 53 tys. ha i była blisko dwukrotnie większa niż powierzchnia uprawy malin (średnio 29 tys. ha). Najmniejszą powierzchnię uprawy truskawek zajmowały w 2010 roku (poniżej 40 tys. ha), a największą w 2006 roku - blisko 60 tys. ha. Uwagę zwracają zbliżone wartości tej cechy w odniesieniu do malin i porzeczek czarnych - średnia 35 tys. ha. Najmniejszą powierzchnię zajmowały uprawy borówek (średnio 7 tys. ha) i pozostałych owoców jagodowych (średnio 1,5 tys. ha). Zmiany powierzchni upraw borówek były najbardziej dynamiczne sposród wszystkich analizowanych gatunków owoców w badanym okresie - od pow. 1 tys. ha w 2006 roku do 8 tys. ha w 2017 roku. Największy wzrost tej powierzchni nastapił w 2010 roku - o 167\% wobec roku wcześniejszego.

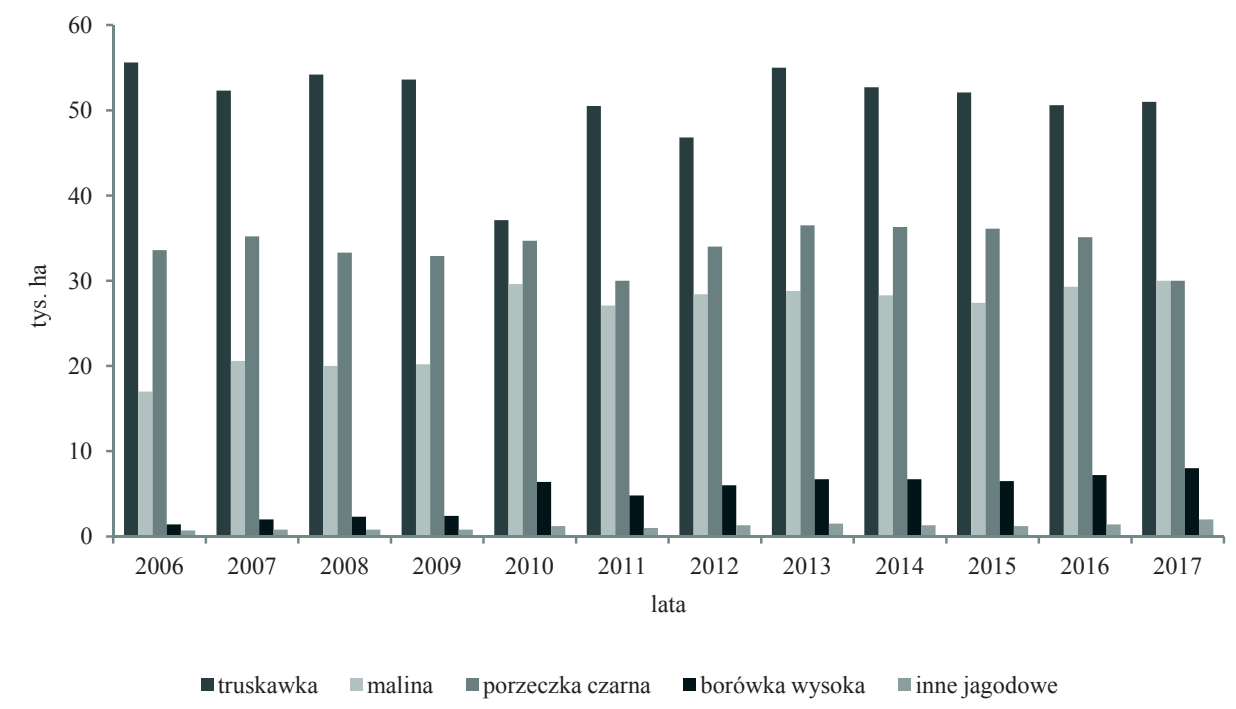

Rys. 1. Powierzchnia uprawy owoców jagodowych w Polsce, w latach 2006-2017

Fig. 1. Cultivation area of berry fruit in Poland, in 2006-2017

Źródło: opracowanie własne na podstawie: Rynek owoców i warzyw, stan i perspektywy, 2017. 
Analizując dynamikę zmian (tab. 1) wartości omawianej cechy (w odniesieniu do roku bazowego 2006) można zauważyć, że największy spadek tej wartości w przypadku truskawek, nastąpił w 2012 roku i wyniósł 16\%. Najmniejszą powierzchnię uprawy malin zaobserwowano w roku bazowym (2006), a największą w ostatnim roku - o 76\% większą niż w roku bazowym. W przypadku porzeczek największy spadek wartości tej cechy nastąpił najpierw w 2001, a następnie w 2017 roku i wyniósł aż 11\%. Borówki zajmowały najmniejszą powierzchnię upraw, podobnie jak maliny, w 2006 roku (blisko 6 razy mniejszą niż wyniosła wartość maksymalna - w 2017 roku.

Tabela 1. Indeksy dynamiki powierzchni upraw owoców jagodowych w Polsce, w latach 2006-2017 (\%)

Table 1. Cultivation area dynamics indexes of berry fruit in Poland, in 2006-2017 (\%)

\begin{tabular}{l|ccccc}
\hline \multirow{2}{*}{ Lata } & Maliny & $\begin{array}{c}\text { Owoce jagodowe } \\
\text { Porzeczki czarne }\end{array}$ & Borówki & Pozostałe \\
\hline 2006 & 100 & 100 & 100 & 100 & 100 \\
2007 & 94 & 121 & 105 & 143 & 114 \\
2008 & 97 & 118 & 99 & 164 & 114 \\
2009 & 96 & 119 & 98 & 171 & 114 \\
2010 & 67 & 174 & 103 & 457 & 171 \\
2011 & 91 & 159 & 89 & 343 & 143 \\
2012 & 84 & 167 & 101 & 429 & 186 \\
2013 & 99 & 169 & 109 & 479 & 214 \\
2014 & 95 & 166 & 108 & 479 & 186 \\
2015 & 94 & 161 & 107 & 464 & 171 \\
2016 & 91 & 172 & 104 & 514 & 200 \\
2017 & 92 & 176 & 89 & 571 & 286 \\
\hline
\end{tabular}

Źródło: opracowanie własne na podstawie: Rynek owoców i warzyw, stan i perspektywy, 2009, 2013 i 2017.

Analizując wartości zbiorów owoców jagodowych w Polsce, w latach 2006-2017 (rys. 2), można wnioskować, że wśród analizowanych gatunków dominowała truskawka (średnio 184 tys. ton). Wielkości zbiorów malin (średnio 97 tys. ton) i porzeczek czarnych (średnio 134 tys. ton) były dość zbliżone i wyraźnie większe od wartości tej cechy w odniesieniu do borówek (średnio 11 tys. ton) i pozostałych owoców jagodowych (średnio 3 tys. ton).

Badania Szuka i in. (2016) wykazały, że Polska była w latach 2008-2013 krajem samowystarczalnym w produkcji owoców jagodowych. Średnia wartość wskaźnika samowystarczalności wyniosła 271\%.

Dynamika zmian wartości omawianej cechy (w odniesieniu do roku 2006) pozwala stwierdzić, że największy wzrost wartości tej cechy nastąpił w przypadku truskawek, o 6\%, w 2015 roku (tab. 2), w przypadku malin o 142\% w 2012 roku, w odniesieniu do porzeczek o 5\% w roku 2013, dla borówek o $227 \%$ w 2017 roku i dla owoców pozostałych o $300 \%$ w tym samym roku. Ponadto w 2010 roku nastąpił wyraźny spadek wartości tej cechy w odniesieniu do truskawek - o 23\% w stosunku do roku 2009. Zbiory malin spadły natomiast aż o 40\% w roku 2015, po wcześniejszym kilkuletnim wzroście i stabilizacji welkości produkcji. W roku 2010, po wcześniejszym wzroście, o 16\% spadła produkcja borówek i utrzymała się na zbliżonym poziomie do 2012 roku. Na obserwowane spadki zbiorów owoców główny wpływ miały niekorzystne warunki pogodowe. 


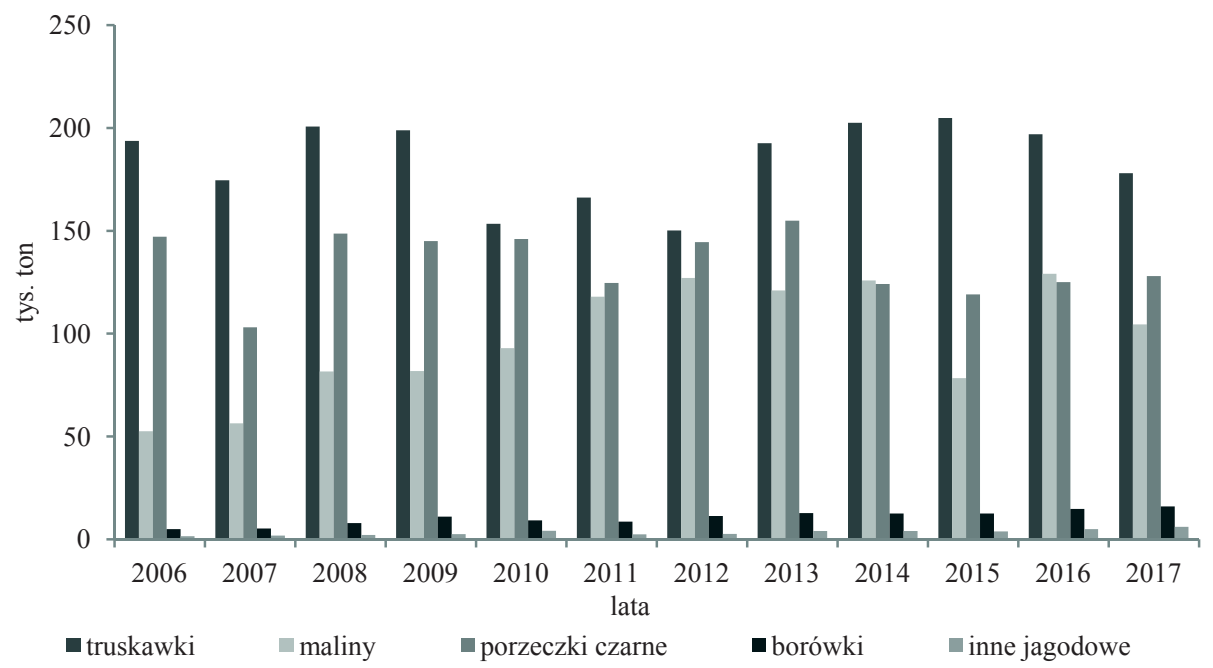

Rys. 2. Produkcja owoców jagodowych w Polsce, w latach 2006-2017

Fig. 2. Production of berry fruit in Poland, in 2006-2017

Źródło: opracowanie własne na podstawie: Rynek owoców i warzyw, stan i perspektywy, 2009, 2013 i 2017.

Interesujące wyniki badań przedstawiła Kierczyńska (2015). W badaniach dotyczących lat 1994-2014 wykazała istotną zależność pomiędzy wielkością produkcji i eksportu w przypadku jabłek, śliwek i wiśni. Natomiast dla porzeczek czarnych, truskawek i malin takiej korelacji nie stwierdzono. Zdaniem autorki obserwowany w tym okresie wzrost produkcji porzeczek czarnych wynikał z rozwijającego się w Polsce przetwórstwa owocowo-warzywnego. Podobnie można wyjaśnić wzrost produkcji malin i truskawek.

Tabela 2. Indeksy dynamiki produkcji owoców jagodowych w Polsce, w latach 2006-2017 (\%)

Table. 2. Production dynamics indexes of berry fruit in Poland, in 2006-2017 (\%)

\begin{tabular}{l|ccccc}
\hline \multirow{2}{*}{ Lata } & & \multicolumn{3}{c}{ Owoce jagodowe } \\
Pruskawki & Maliny & Porzeczki czarne & Borówki & Pozostałe \\
\hline 2006 & 100 & 100 & 100 & 100 & 100 \\
2007 & 90 & 107 & 70 & 106 & 120 \\
2008 & 104 & 155 & 101 & 161 & 140 \\
2009 & 103 & 156 & 99 & 224 & 167 \\
2010 & 79 & 177 & 99 & 188 & 273 \\
2011 & 86 & 225 & 85 & 176 & 160 \\
2012 & 78 & 242 & 98 & 231 & 173 \\
2013 & 99 & 230 & 105 & 259 & 267 \\
2014 & 105 & 240 & 84 & 255 & 267 \\
2015 & 106 & 149 & 81 & 300 & 253 \\
2016 & 102 & 246 & 85 & 327 & 327 \\
2017 & 91 & 190 & 68 & 400 \\
\hline
\end{tabular}

Źródło: opracowanie własne na podstawie: Rynek owoców i warzyw, stan i perspektywy, 2009, 2013 i 2017. 
Dane przedstawione w tabeli 3 pozwalają stwierdzić, że udział Polski w produkcji światowej, w 2016 roku okazał się znaczący, w odniesieniu do truskawek (8 miejsce), malin (miejsce 3) i borówek (miejsce 4).

Ponadto badania Ciebienia i in. (2015), dotyczące lat 2003 - 2012, wykazały, że wielkość produkcji malin w Polsce stanowiła od 10\% (w 2003 roku) do 21\% (w 2012 roku) produkcji światowej, a w europejskiej odpowiednio od $12 \%$ do $28 \%$.

Tabela 3. Produkcja owoców jagodowych w wybranych krajach, w 2016 roku

Table 3. Berry fruit production in selected countries, in 2016

\begin{tabular}{l|rrrrrr}
\hline \multirow{2}{*}{ Wyszczególnienie } & \multicolumn{3}{|c}{ Wielkość produkcji (tys. ton) } & \multicolumn{2}{c}{ Udział w produkcji światowej (\%) / lokata } \\
& Truskawki & \multicolumn{1}{c}{ Maliny } & \multicolumn{1}{c}{ Borówki } & Truskawki & \multicolumn{1}{c}{ Maliny } & \multicolumn{1}{c}{ Borówki } \\
\hline Świat & 9118336 & 795249 & 552505 & 100 & 100 & 100 \\
Polska & 196972 & 129063 & 14721 & $2,2 / 8$ & $16 / 3$ & $2,7 / 4$ \\
Niemcy & 143221 & 5617 & 10710 & $1,6 / 11$ & $0,7 / 15$ & $1,9 / 5$ \\
Francja & 58737 & 4030 & 9352 & $0,6 / 17$ & $0,5 / 16$ & $1,7 / 6$ \\
Portugalia & 8495 & 16972 & 6572 & $0,1 / 40$ & $2,1 / 10$ & $1,2 / 8$ \\
Hiszpania & 366161 & 17808 & 6412 & $4,0 / 6$ & $2,2 / 9$ & $1,2 / 9$ \\
Holandia & 57500 & 1820 & 7919 & $0,6 / 19$ & $0,2 / 23$ & $1,4 / 7$ \\
Włochy & 131436 & 2245 & 1683 & $1,4 / 13$ & $0,3 / 20$ & $0,3 / 15$ \\
Chiny & 3801865 & bd & bd & $42 / 1$ & $b d$ & $b d$ \\
Rosja & 197523 & 164602 & 3292 & $2,2 / 7$ & $21 / 1$ & $60 / 11$ \\
Kanada & 21858 & 10792 & 178745 & $2,4 / 30$ & $1,4 / 13$ & $32 / 2$ \\
USA & 1420570 & 137829 & 269257 & $16 / / 2$ & $17 / 2$ & $49 / 1$ \\
\hline
\end{tabular}

Źródło: opracowanie własne na podstawie danych FAO i www.factfish.com.

Analizując powierzchnię upraw (tab. 4) można stwierdzić, że Polska uzyskała lepsze lokaty niż w odniesieniu do wielkości produkcji, odpowiednio 2, 1 i 3. Wskazywałoby to na mniejszą wydajność produkcji niż w pozostałych krajach. Niemcy uzyskały znacznie niższą lokatą $\mathrm{w}$ zakresie powierzchni uprawy niż produkcji, ale jedynie $\mathrm{w}$ przypadku truskawek. We Francji udział w strukturze powierzchni był zgodny z udziałem w strukturze produkcji dla borówek, a udział w produkcji pozostałych owoców był korzystniejszy od udziału w powierzchni upraw. Portugalia charakteryzowała się dużą wydajnością produkcji truskawek. Świadczy o tym 18-punktowa różnica lokat ze względu na udział w produkcji i w powierzchni uprawy. Dużą wydajność produkcji truskawek i malin zaobserwowano w przypadku Hiszpanii i Włoch. Podobne zjawisko w odniesieniu do wszystkich badanych gatunków stwierdzono w Holandii i USA. Ponadto powierzchnia uprawy malin w Polsce stanowiła od 14\% (w 2003 roku) do $26 \%$ (w 2012 roku) światowej powierzchni upraw oraz od 16\% do 31\% europejskiej powierzchni upraw (Ciebień i in. 2015).

Spożycie owoców w Polsce (tab. 5) było największe w 2009 roku, o 10\% większe od wartości w roku bazowym (rys. 3), a w 2008 roku wartość tej cechy była większa o 4\% w odniesieniu do roku 2006. W analizie rok do roku można zauważyć początkowe zmniejszenie wartości omawianej cechy o 2\%, jednak już w kolejnym, 2008 roku, spożycie zwiększyło się aż o 19\%, a rok później było o kolejne $6 \%$ większe. Jednak w kolejnych latach zanotowane nieregularne wahania omawianych wartości $\mathrm{z}$ tendencją wzrostową w latach 2011-2015, by w ostatnim roku badań osiagną́ poziom o blisko $15 \%$ niższy niż w roku bazowym. Ponadto wartości współczynników korelacji wskazały na istotną dodatnią 
zależność spożycia owoców ogółem i owoców jagodowych $(\mathrm{r}=0,75 ; \mathrm{p}=0,005)$ oraz ujemną istotną korelację spożycia jabłek i owoców południowych $(\mathrm{r}=-0,92 ; \mathrm{p}=0,000)$.

Tabela 4. Udział w powierzchni światowej upraw owoców jagodowych w wybranych krajach, w 2016 roku Table 4. Berry fruit share in the area of world crops in selected countries, in 2016

\begin{tabular}{l|ccc}
\hline \multicolumn{1}{c|}{ Wyszczególnienie } & $\begin{array}{c}\text { Udział w powierzchni światowej upraw owoców jagodowych (\%) / lokata } \\
\text { Truskawki }\end{array}$ & $\begin{array}{c}\text { Maliny } \\
\text { Borówki }\end{array}$ \\
\hline Świat & 100 & 100 & 100 \\
Polska & $13 / 2$ & $0,3 / 1$ & $4,5 / 3$ \\
Niemcy & $3,6 / 6$ & $1,0 / 15$ & $2,4 / 5$ \\
Francja & $0,8 / 19$ & $0,6 / 17$ & $2,2 / 6$ \\
Portugalia & $0,1 / 58$ & $\mathrm{bd}$ & $\mathrm{bd}$ \\
Hiszpania & $1,9 / 11$ & $1.7 / 12$ & $\mathrm{bd}$ \\
Holandia & $0,4 / 26$ & $0,2 / 26$ & $0,7 / 9$ \\
Włochy & $1,2 / 15$ & $0,3 / 22$ & $0,2 / 15$ \\
Chiny & $35 / 1$ & $\mathrm{bd}$ & $\mathrm{bd}$ \\
Rosja & $7 / 3$ & $20 / 2$ & $0,6 / 10$ \\
Kanada & $0,7 / 21$ & $2 / 10$ & $49 / 1$ \\
USA & $5,3 / 4$ & $8,2 / 4$ & $0,3 / 2$ \\
\hline
\end{tabular}

Źródło: opracowanie własne na podstawie danych FAO i www.factfish.com

Pozytywne tendencje w odniesieniu do spożycia owoców jagodowych były w pewnej mierze związane z modą na zdrowy tryb życia, która promuje zastępowanie tradycyjnych przekąsek owocami i warzywami. Jednak zwiększone zainteresowanie spożywaniem owoców skupiło się przede wszystkim na owocach południowych (głównie owoce cytrusowe i banany), których spożycie w analizowanych latach 2006-2017 wzrosło wyraźnie - aż o 48\%, jednak w przypadku owoców ogółem ten wzrost wyniósł jedynie 1\%, a w przypadku jabłek zanotowano spadek spożycia aż o $33 \%$.

Tabela 5. Spożycie owoców jagodowych w Polsce, w gospodarstwach domowych (w kg/ miesiąc, na osobę), w latach 2006-2017

Table 5. Berry fruit consumption in Poland, in households (in $\mathrm{kg} / 1 \mathrm{month}, 1$ person), in 2006-2017

\begin{tabular}{c|cccc}
\hline Lata & ogółem $^{1}$ & Jagodowe/udział w ogółem (\%) & jabłka & południowe \\
\hline 2006 & 3,41 & $0,48 / 14,08$ & 1,49 & 0,89 \\
2007 & 3,26 & $0,42 / 12,88$ & 1,31 & 0,97 \\
2008 & 3,44 & $0,50 / 14,53$ & 1,25 & 1,00 \\
2009 & 3,63 & $0,53 / 14,60$ & 1,35 & 0,95 \\
2010 & 3,28 & $0,42 / 12,80$ & 1,25 & 1,05 \\
2011 & 3,13 & $0,39 / 12,46$ & 1,10 & 1,06 \\
2012 & 3,30 & $0,41 / 12,42$ & 1,26 & 1,02 \\
2013 & 3,28 & $0,43 / 13,11$ & 1,13 & 1,11 \\
2014 & 3,44 & $0,47 / 13,66$ & 1,17 & 1,12 \\
2015 & 3,45 & $0,46 / 13,33$ & 1,05 & 1,22 \\
2016 & 3,50 & $0,43 / 12,29$ & 1,08 & 1,25 \\
2017 & 3,46 & $0,41 / 11,85$ & 1,00 & 1,32 \\
\hline
\end{tabular}

${ }^{1}$ owoce świeże, chłodzone lub mrożone.

Źródło: opracowanie własne na podstawie danych GUS, „Budżety gospodarstw domowych”, lata 2006-2017. 
Podobną tendencję dotyczącą owoców południowych stwierdzono w badaniach Jąder (2014) - udział owoców południowych w konsumpcji owoców świeżych wzrósł z 23\% w latach 1998-2002 do 30\% w latach 2008-2012. Ponadto zaobserwowano niewielkie zmiany $\mathrm{w}$ analizowanym piętnastoleciu, w odniesieniu do konsumpcji owoców jagodowych oraz pozostałych owoców, a wyznaczona prosta regresji wykazała w ich przypadku jedynie minimalną tendencję malejącą. W latach 1998-2012 średnie spożycie owoców jagodowych wyniosło $5,56 \mathrm{~kg} / \mathrm{os}$./rok i zmniejszało się średnio co roku o $0,029 \mathrm{~kg}$, w tempie bliskim 0 .

Uwzględniając podział terytorialny Polski zaobserwowano w latach 2008-2013, że wyższy poziom spożycia owoców $\mathrm{w}$ przeliczeniu na mieszkańca wystapił w województwach o najwyższych wskaźnikach samowystarczalności (Szuk i in. 2016).

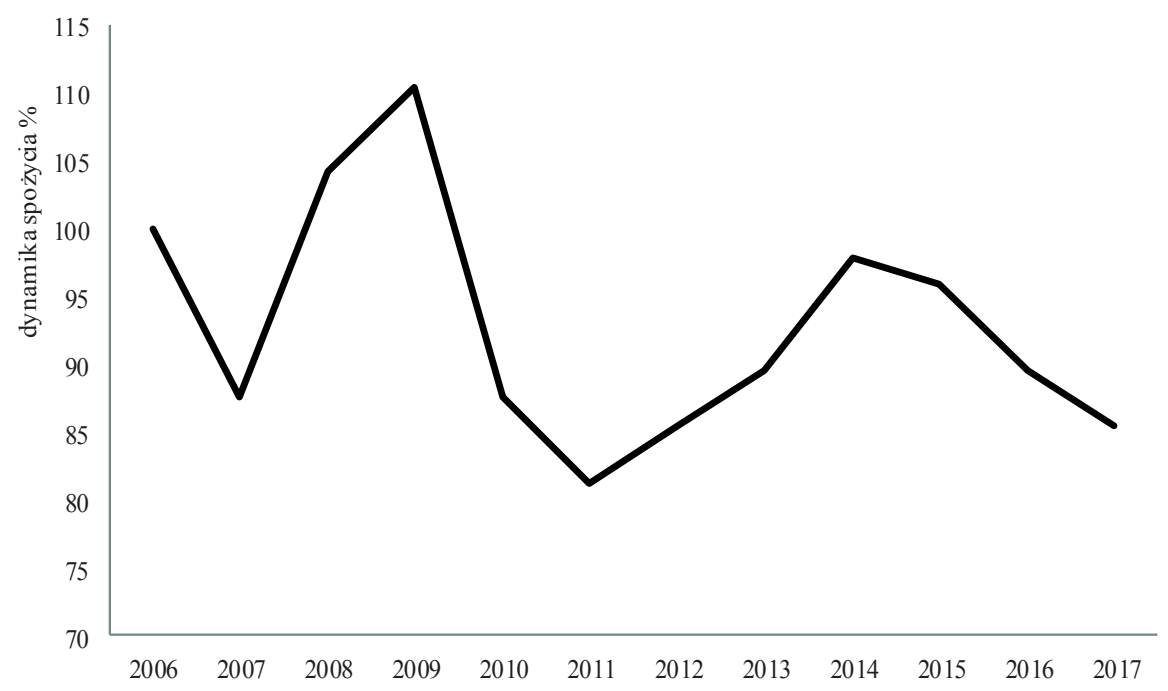

Rys. 3. Indeksy dynamiki spożycia owoców jagodowych w Polsce, w latach 2006-2017

Fig. 3. Consumption dynamics indexes of berry fruit in Poland, in 2006-2017 (\%)

Źródło: opracowanie własne na podstawie danych GUS, „Budżety gospodarstw domowych”, lata 2006-2017.

W badaniach przeprowadzonych na dziewczętach i kobietach ciężarnych (Szczepaniak, 2004) stwierdzono, że najczęściej spożywane były jabłka, następnie cytryny, truskawki, pomarańcze i banany.

Z badań przeprowdzonych przez Kamelską i in. (2011), wynika, że kobiety ciężarne z owoców krajowych najczęściej wybierały jabłka (48\%), następnie winogrona $(16 \%)$ i truskawki (13\%). Spożycie malin wyniosło jedynie 3\%. Wśród owoców egzotycznych główny udział w diecie kobiet ciężarnych stanowiły banany (25\%) oraz pomarańcze (28\%). Kobiety często spożywały również mandarynki (17\%). Podobne wyniki uzyskano w odniesieniu do kobiet karmiących, które najchętniej spożywały jabłka (59\%), w znacznie mniejszych ilościach czereśnie (4\%), truskawki (9\%) i maliny (3\%). Potwierdziło się również wysokie spożycie owoców południowych. Najchętniej wybierane były banany $(47 \%)$, następnie mandarynki (19\%) oraz pomarańcze $(14 \%)$. 


\section{Podsumowanie}

Owocowe jagodowe stanowią bardzo ważny składnik zdrowej diety i charakteryzują się właściwościami leczniczymi. Zawierają garbniki, procyjanidyny B1 i B4, flawonoidy, kwasy organiczne i kwas elagowy. Są bogate w polifenole, witaminy i związki mineralne, węglowodany, kwasy organiczne, pektyny, aminokwasy, enzymy, glukozydy, flawonoidy, antocyjany, olejki eteryczne, glikozydy, cyjanidyny i delfinidyny. Jednak ich spożycie w Polsce ulegało nieregularnym zmianom w badanym okresie, a spadek wartości analizowanego wskaźnika pomiędzy rokiem 2006 a 2017 wyniósł aż 15\%.

Największą powierzchnię upraw truskawek zanotowano w 2006 roku, a największą produkcję w 2017 roku. Największą powierzchnię uprawy malin stwierdzono w 2017 roku, a największą wartość produkcji w 2016 roku. W odniesieniu do porzeczek czarnych największą powierzchnią charakteryzował się rok 2014, a największą produkcją rok 2013. Natomiast powierzchnia uprawy oraz wielkość produkcji borówek osiągnęły maksymalne wartości w 2017 roku.

Analiza porównawcza pozwoliła wnioskować, że udział Polski w produkcji światowej, w 2016 roku był znaczący. Wielkość produkcji truskawek w Polsce była na 8 miejscu w rankingu krajów producentów, w przypadku malin było to miejsce 3, a borówek miejsce 4. Jednocześnie pod względem powierzchni upraw Polska uzyskała lepsze lokaty, odpowiednio 2, 1 i 3 . Wskazywałoby to na mniejszą wydajność produkcji niż w pozostałych krajach producentach.

Zmiany w wielkościach spożycia poszczególnych grup owoców opisane współczynnikami korelacji sugerują, że zmiany w spożyciu owoców jagodowych powodują podobne zmiany w spożyciu owoców ogółem, natomiast spadek zainteresowania spożywaniem jabłek spowodował wyraźny wzrost spożycia owoców południowych, które są łatwo dostępne w sklepach wielkopowierzchniowych za stosunkowo niską cenę. Owoce jagodowe odpowiedniej jakości są trudniej dostępne dla klienta. Jabłka natomiast cieszą się malejącym zainteresowaniem, pomimo dużej dostępności.

\section{Literatura}

Ciebień, M., Rachoń, L., Krawiec, P. (2015). Pozycja polski w światowej produkcji malin w latach 2003-2012 (Position of Poland in the world production of raspberries in the years 2003-2012). Roczniki Naukowe Stowarzyszenie Ekonomistów Rolnictwa i Agrobiznesu, 17(2), 16-19.

Gheribi, E. (2012). Konsumpcja owoców i warzyw w polskich gospodarstwach domowych w latach 2004-2008 (Fruit and vegetable consumption in Polish households in 2004-2008). Zeszyty Naukowe SGGW $w$ Warszawie, Ekonomika i Organizacja Gospodarki Żywnościowej, 95, 67-77.

Jabłońska, L. (2006). Wspólna organizacja rynku owoców w UE jako czynnik zwiększania konkurencyjności sektora sadowniczego w Polsce (Common organization of the fruit market in the EU as a factor increasing the competitiveness of the fruit sector in Poland). Mat. Konf. „Czynniki wpływające na plonowanie i jakość owoców roślin sadowniczych, II Międzynarodowe Targi Agrotechniki Sadowniczej, Warszawa 13-14 stycznia, 159-164.

Jąder, K. (2014). Zmiany w konsumpcji owoców i ich przetworów w Polsce w latach 1998-2012 (Changes in the consumption of fruit and their conventions in Poland in the years 1998-2012). Roczniki Naukowe Ekonomii Rolnictwa i Rozwoju Obszarów Wiejskich, 101(3), 98-106.

Jąder, K. (2017). Zróżnicowanie preferencji i zachowań konsumentów owoców i ich przetworów w zależności od wieku oraz dochodów (Diversity of preferences and behaviors of consumers of fruits and their products depending on their age and income). Roczniki Naukowe Stowarzyszenia Ekonomistów Rolnictwa i Agrobiznesu, 19(4), 97-103. 
Kamelska, A.M., Pietrzak-Fiećko, R., Bryl, K., Nowakowski, J.J. (2011). Próba oceny zachowań żywieniowych oraz spożycia wybranych owoców grupy kobiet ciężarnych i karmiących (An attempt to assess the nutritional behavior and consumption of selected fruits of a group of pregnant and lactating women). Bromatologia i Chemia Toksykologiczna, 44(3), 1009-1014.

Karabela, M. (2006). Truskawka (Strawberry). Panacea, 2(15), 24-26.

Karabela, M. (2008). Czarna porzeczka (Black currant). Panacea, 1(22), 30-31.

Kierczyńska, S. (2015). Produkcja i eksport owoców w Polsce w latach 1994-2014 (Fruit production and export in Poland in the 1994-2014). Roczniki Naukowe Stowarzyszenie Ekonomistów Rolnictwa i Agrobiznesu, 17(5), 131-135.

Krauze-Baranowska, M. (2007). Malina czerwona, Owoce maliny - właściwości dietetyczne i lecznicze (Red raspberry, Raspberry fruit - dietetic and healing properties). Panacea, 4(21), 22-23.

Paszko, D., Pawlak, J., Wróblewska, W. (2016). Wahania koniunktury w produkcji owoców jagodowych w Polsce i na świecie (Fluctuations of the economic situation in the production of berries in Poland and in the world). Zeszyty Naukowe SGGW w Warszawie, Problemy Rolnictwa Światowego, 17(3), 301-312.

Pliszka, K. (red.) (2002). Borówka wysoka (Highbush blueberry). Państwowe Wydawnictwa Rolnicze i Leśne, Warszawa.

Sobczak, W., Jabłońska, L., Olewnicki, D. (2013). Stopień zorganizowania producentów owoców i warzyw w Polsce (Degree of organizing fruit and vegetable producers in Poland). Zeszyty Naukowe SGGW w Warszawie, Problemy Rolnictwa Światowego, 13(1), 119-127.

Szczepaniak, B., Górecka, D., Flaczyk, E. (2004). Preferencje i częstotliwość spożycia owoców wśród dziewcząt oraz kobiet w ciąży (Preferences and frequency of fruit consumption among girls and pregnant women). Acta Scientiarum Polonorum. Technologia Alimentaria, 3(1), 175-185.

Szuk, T., Kutkowska, B., Stachowiak, M. (2016). Samowystarczalność w produkcji owoców w Polsce w ujęciu regionalnym (Self-sufficiency in fruit production in Poland on a regional basis). Roczniki Naukowe Stowarzyszenie Ekonomistów Rolnictwa i Agrobiznesu, 18(2), 266-271.

Tomek, W.G., Robinson, K.L. (2001). Kreowanie cen artykułów rolnych (Creating prices of agricultural products). PWN, Warszawa.

Portal promocji eksportu (Export promotion portal). Pobrano z: https://www.trade.gov.pl/pl.

Rynek owoców i warzyw: stan i perspektywy (Fruit and vegetable market: state and prospects). (2010). Praca zbiorowa, Instytut Ekonomiki Rolnictwa i Gospodarki Żywnościowej - Instytut Badawczy, z. 37.

Rynek owoców i warzyw: stan i perspektywy (Fruit and vegetable market: state and prospects). (2014). Praca zbiorowa, Instytut Ekonomiki Rolnictwa i Gospodarki Żywnościowej - Instytut Badawczy, z. 45.

Rynek owoców i warzyw: stan i perspektywy (Fruit and vegetable market: state and prospects). (2018). Praca zbiorowa, Instytut Ekonomiki Rolnictwa i Gospodarki Żywnościowej - Instytut Badawczy, z. 53.

Do cytowania / For citation:

Grużewska A., Zarzecka K., Gugała M. (2018). Analiza rynku owoców jagodowych - wybrane elementy. Problemy Rolnictwa Światowego, 18(4), 152-161; DOI: 10.22630/PRS.2018.18.4.106

Grużewska A., Zarzecka K., Gugała M. (2018). Analysis of the Berry Market - Selected Elements (in Polish). Problems of World Agriculture, 18(4), 152-161; DOI: 10.22630/PRS.2018.18.4.106 